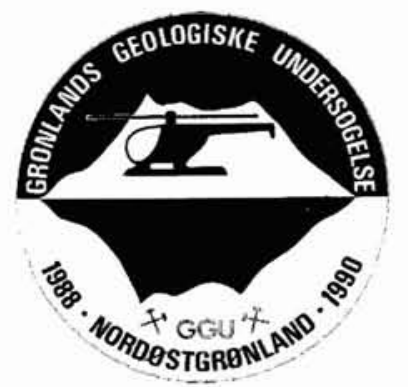

\title{
Structure of the Eleonore Bay Supergroup at Ardencaple Fjord, North-East Greenland
}

\author{
A. K. Higgins and N. J. Soper
}

The Caledonian structures in the late Proterozoic Eleonore Bay Supergroup of the Ardencaple Fjord area were controlled by the position and shape of the contacts with older basement rocks. Those contacts that are not late faults are likely to have been extensional shear zones of Vendian age which were reactivated in compression during the Caledonian orogeny. This interpretation may also be applied to the other large tracts of low grade Eleonore Bay Supergroup sediments in East Greenland, and explains their preservation at the present erosion level, surrounded by Precambrian basement rocks.

A. K. H., Geological Survey of Greenland, Øster Voldgade 10, DK-1350 Copenhagen $K$, Denmark.

N. J. S., Department of Earth Sciences, University of Leeds, Leeds LS2 9JT, U.K.

The Eleonore Bay Supergroup (EBG) is one of the major clastic sequences of Late Proterozoic age that are preserved within the North Atlantic Caledonides. It is exposed in East Greenland between latitudes $72^{\circ}$ and $76^{\circ} \mathrm{N}$ in a number of tracts that are surrounded by earlier Proterozoic and Archaean schists and gneisses (Fig. 1); the outcrops around Ardencaple Fjord (Fig. 2) make up the northernmost of these tracts.

The Eleonore Bay Supergroup consists of a dominantly shallow marine sequence of quartzites and shales that pass up into carbonates, and totals up to $16 \mathrm{~km}$ in thickness. Sønderholm \& Tirsgaard (1993) in their revision of the lithostratigraphy of the EBG (which they upgrade to supergroup status) have emphasised the uniformity of upper EBG stratigraphy over the whole of its outcrop in East Greenland, a north-south distance of 500 $\mathrm{km}$. It would appear that the sequence was deposited on a vast shelf continuously subsiding for a period of $200 \mathrm{Ma}$, or more.

The EBG crops out in three main regions in East Greenland (Fig. 1): the so-called central fjord zone centred on Kejser Franz Joseph Fjord and Kong Oscar Fjord; the Petermann Bjerg region to the west near the Inland Ice; and the Ardencaple Fjord area in the north. In the central fjord zone the EBG is overlain conformably by the Vendian Tillite Group, a clastic sequence up to $1.3 \mathrm{~km}$ thick that contains two glacigenic formations (Hambrey \& Spencer, 1987), which in turn is followed with slight unconformity by some $3 \mathrm{~km}$ of Cambro-Ordovician dominantly carbonate sediments.
All three main EBG regions exhibit a downward transition from non-metamorphic sediments through metasediments into crystalline gneisses, a phenomenon which was formerly interpreted as due to the rise of a Caledonian migmatite front into the EBG sedimentary pile (e.g. Wegmann, 1935; Haller, 1971). This concept has been shown to be untenable as a consequence of isotopic studies during the past two decades (e.g. Rex \& Gledhill, 1981; Steiger et al., 1979), which have shown that the infracrustal gneiss complexes comprise substantial Archaean and early Proterozoic components on which Caledonian orogenic events were superimposed.

Study of the northernmost EBG outcrops around Ardencaple Fjord by the authors in 1988 has provided insights into the nature of the EBG/basement contact, and also into the problem of how extensive remnants of the EBG cover sequence came to be preserved as enclaves within the older metamorphic basement after Caledonian deformation and uplift. Soper \& Higgins (1993) infer that the EBG is preserved in pre-Caledonian grabens, which were incompletely inverted during the Caledonian orogeny; the graben-forming rift episode is dated as Vendian. The present contacts between EBG cover and Proterozoic (or older) basement, where not obscured by post-Caledonian faulting, take the form of extensional shear zones associated with this rift episode which were reactivated in compression during the Caledonian orogeny.

The present paper describes the structures which developed in the Ardencaple Fjord area EBG outcrops as a consequence of the rifting and compressional episodes. 


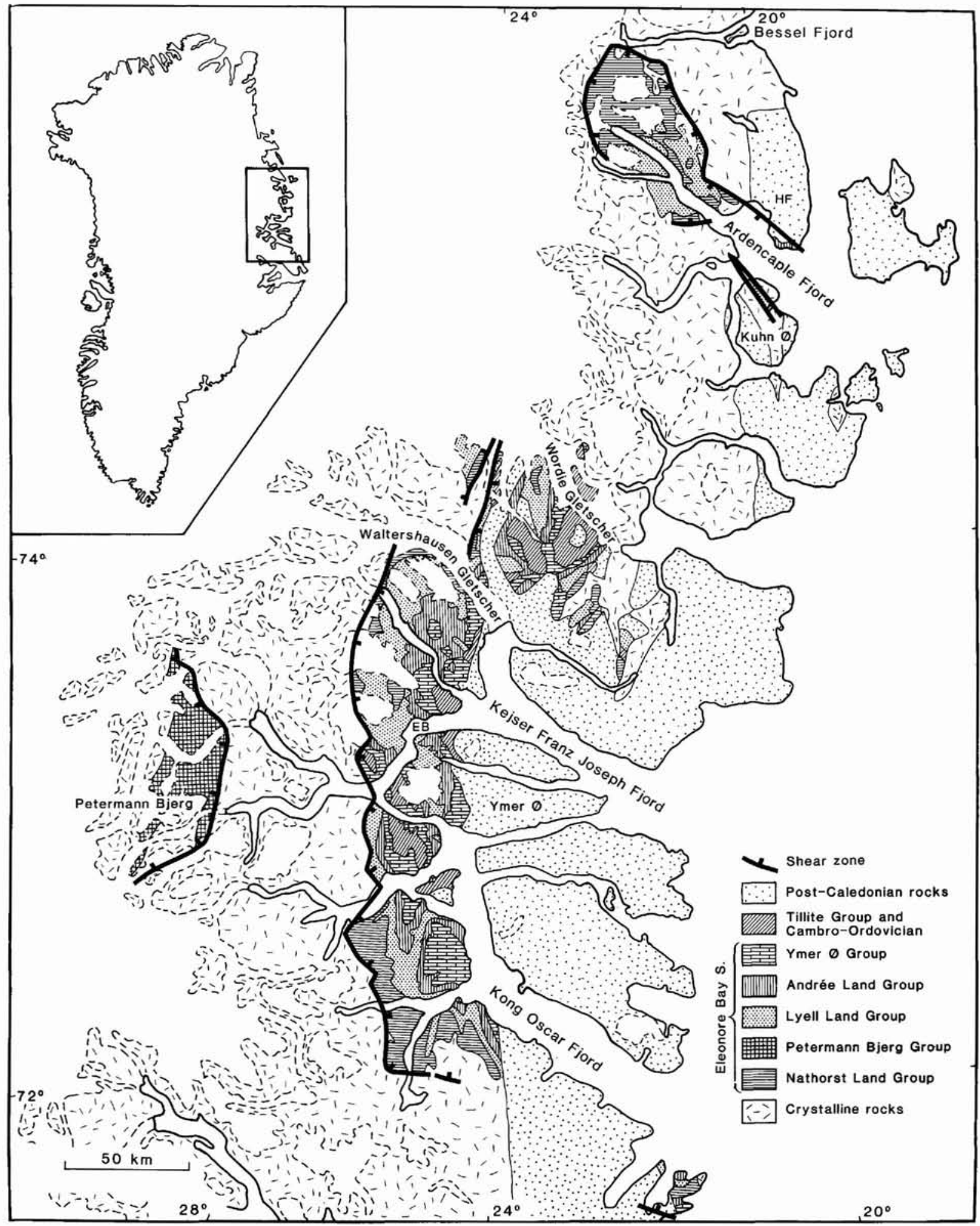

Fig. 1. Map showing main outcrops of the Eleonore Bay Supergroup, Tillite Group and Cambro-Ordovician strata in East Greenland. Postulated Vendian shear zones also shown. HF: Hochstetter Forland; EB: Eleonore Bugt. 


\section{The Eleonore Bay Supergroup of Ardencaple Fjord}

The most northerly occurrence of Eleonore Bay Supergroup rocks in East Greenland occupies a 75 by $40 \mathrm{~km}$ area centred on Ardencaple Fjord and its two inner branches, Smallefjord and Bredefjord (Fig. 2); northwards the main tract reaches almost to Bessel Fjord while detached outcrops are present in the southern part of Hochstetter Forland and in a fault-bounded strip in northern Kuhn $\emptyset$ (Fig. 1). The main EBG tract is surrounded mainly by high grade migmatitic semipelitic and psammitic schists (Smallefjord sequence) which are thought to be of mid-Proterozoic age and to predate the EBG (Friderichsen et al., 1994); gneisses and granitic rocks to the west of the EBG tract have yielded early Proterozoic Sm-Nd model ages (Kalsbeek, et al., 1993). The southwestern border of the main EBG tract consists of postCaledonian faults which are also prominent within the EBG rocks on both sides of Ardencaple Fjord. The western and north-eastern borders are defined by ductile shear zones.

The Ardencaple Fjord tract of EBG rocks was discovered during sledge trips and reconnaissance flights in the 1930 s, but the only detailed fieldwork prior to 1988 was one month, undertaken by Max Sommer in 1955 and supplemented by reconnaissance flights with Norseman aircraft (Sommer, 1957). He was able to establish correlation with the EBG of the central fjord zone and define the principal folds and faults. Haller made further aerial observations and an air photograph study, and in his descriptions and structural maps (Haller, 1970, 1971) distinguished older (main Caledonian) NNE-SSW trending and younger (Devonian) NW-SE trending structures. The Ardencaple Fjord EBG tract is described as let down in a graben-like depression, with normal faults along the west and south-west margins but with a SW-dipping thrust along the whole north-east boundary, along which EBG rocks in the hangingwall had been carried north-east over Caledonian gneisses and metasediments (see Haller, 1971, figure 93).

Fieldwork by the authors in 1988 has clarified some of the structural problems posed by the Ardencaple EBG, as described below. Stratigraphic studies made at the same time have strengthened correlation with the EBG of the central fjord zone (Sønderholm et al., 1989; Sønderholm \& Tirsgaard, 1993).

\section{Stratigraphy}

The stratigraphy of the main EBG tract at Ardencaple Fjord is summarised in the legend to Figure 2, using the new lithostratigraphic classification of Sønderholm \& Tirsgaard (1993).

At least $2 \mathrm{~km}$ of the Nathorst Land Group ('lower EBG') is present, forming the high mountainous terrain north of Bredefjord (Fig. 2). It consists of alternating units of quartz arenite, interbedded sandstone and mudstone, and black silty mudstone. Lithostratigraphic subdivisions can be made in the steep cliffs of inner Bredefjord (Fig. 3), but can rarely be traced inland. At fjord level the metamorphic grade reaches amphibolite facies, with strong fabric development leading to the obliteration of most sedimentary structures, so that Sønderholm et al. (1989) were unable to make a firm interpretation of the depositional environment.

Close to $2 \mathrm{~km}$ of the Lyell Land Group (the Quartzite Series of earlier classifications) are present in the main tract, principally in the east, on both sides of Ardencaple Fjord. Six mapping units can be recognised, ranging from 240 to $700 \mathrm{~m}$ in thickness, now adopted as formations. They comprise white, brown and purple weathering quartz arenites and dark green, brown and deep red silty mudstones. The formations are readily correlated with the type formations in the central fjord zone several hundred kilometres to the south, for which a siliciclastic marine shelf environment has been suggested. Acritarchs isolated from the upper part of the Lyell Land Group in the type area suggest a Sturtian (late Riphean) age (Vidal, 1976, 1979).

The isolated sequence on Kuhn $\emptyset$ comprises $650 \mathrm{~m}$ of mixed metasediments ascribed uncertainly to the Nathorst Land Group or lower Lyell Land Group, while the isolated outcrops on Hochstetter Forland are referred to the Ymer $\emptyset$ Group (which overlies the Lyell Land Group: Sønderholm \& Tirsgaard, 1993).

\section{Structure}

Over most of the area the EBG is subhorizontal or gently warped into broad open folds, but there are several belts of more intense folding (Fig. 2). One is associated with the north-east margin where subhorizontal strata turn down sharply to the north-east in an anticline which trends generally NNW-SSE parallel to the margin; this Troldedalen anticline can be traced for about $40 \mathrm{~km}$ south-westwards from Troldedalen, and over a short distance is accompanied by a complementary syncline. An approximately parallel pair of major folds, the Brædal anticline and syncline, can be traced for about $40 \mathrm{~km}$ along the north-east coast of Ardencaple Fjord and Bredefjord; however, vergence is to the south-west the opposite sense to the Troldedalen structure.

Other major structures in the EBG tract (Fig. 2) include a syncline along Ejnar Mikkelsen Gletscher and Knæks $\emptyset$ 


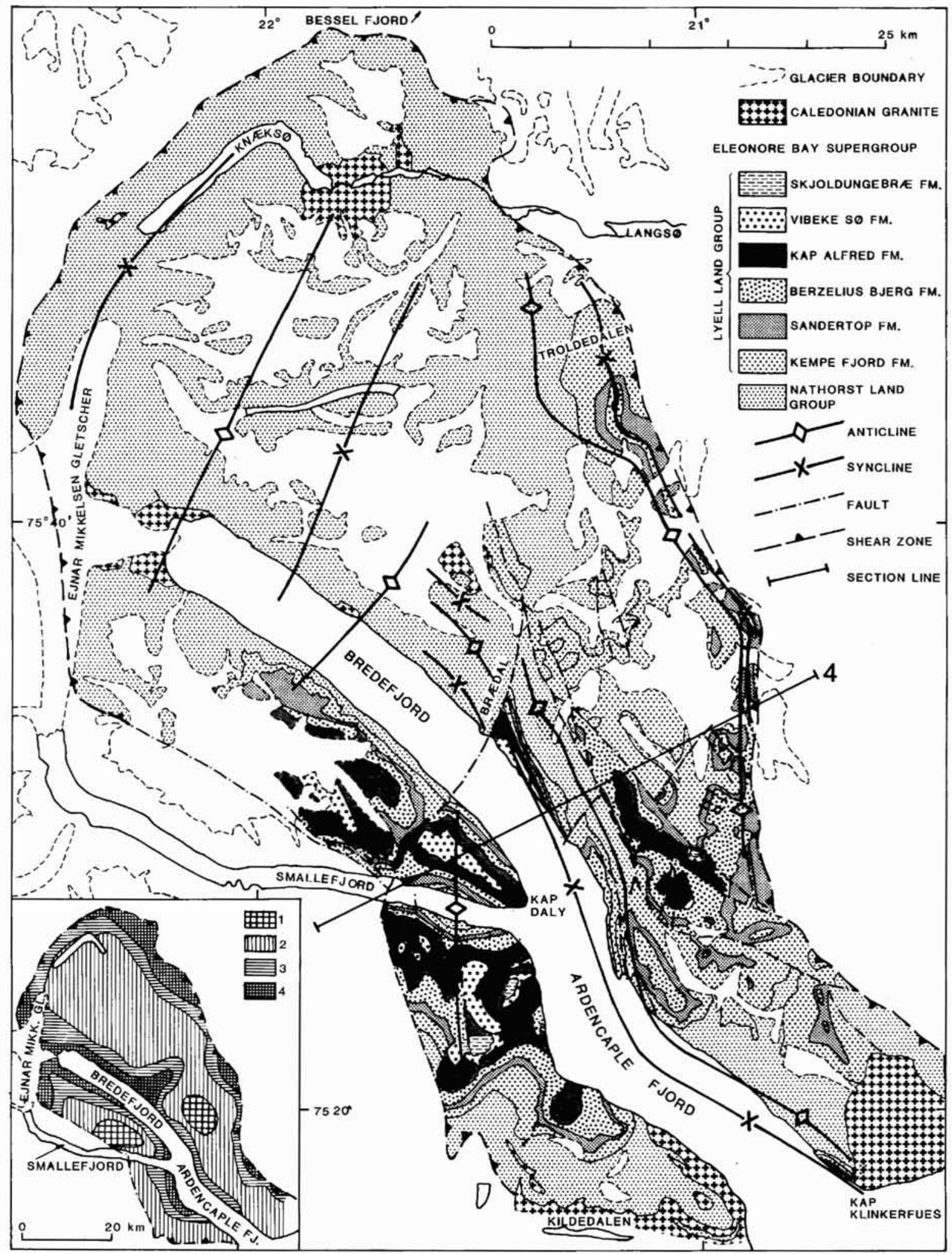

Fig. 2. Stratigraphic and structural map of the Eleonore Bay Supergroup around Ardencaple Fjord. Pre-EBG basement rocks unornamented. 4, cross-section 4 in Figure 9. Inset map shows generalised metamorphic zonation of the EBG: 1 - detrital textures; 2 - recrystallised; 3 - biotite; 4 - garnet and staurolite. After Soper \& Higgins (1993). 
Fig. 3. Flat-lying Nathorst Land Group (undivided) on the south side of Bredefjord. Pale quartzites of the Kempe Fjord Formation (K) cap the highest summits $(1700 \mathrm{~m})$.

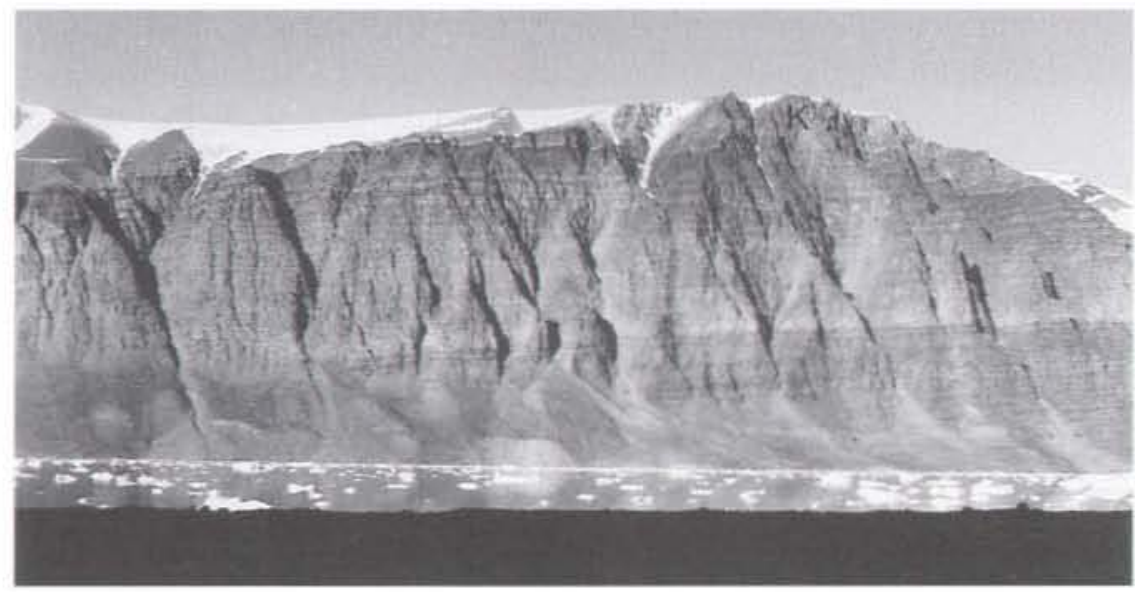

(the Knakso syncline), broad NNE-SSW trending folds parallel to the Knækss syncline, and a pronounced N-S trending anticline crossing the mouth of Smallefjord (the Smallefjord anticline), which is complementary to the Bredal fold pair.

\section{Troldedalen fold pair}

The Troldedalen fold pair follows the north-east margin of the EBG outcrop. Subhorizontal strata tum down sharply to form an east to north-east verging anticline (Fig. 4). usually accompanied by a complimentary tight syncline. The common steep limb of the fold pair is inverted and passes down into a strongly sheared zone in which sedimentary way up indicators are obliterated; strain and metamorphic grade of the EBG increase downwards towards the contact with the subjacent schists (Smallefjord sequence). The folds verge to the north-east away from the EBG tract, and the shear zone thus appears to have a thrust sense of displacement, even though it contains (younger) EBG cover rocks in the hangingwall.
Traced from north-west to south-east the profile of the fold pair in constructed cross-sections (Fig. 9) changes significantly. Around Troldedalen the anticline and syncline are both clearly delineated, the syncline prominently exposed on the south wall of the valley with a core formed by dark quartzite and shale of the Kap Alfred Formation. Towards the south the axial traces of both folds approach the shear zone more closely. the syncline becoming isoclinal and strongly sheared; it can usually be recognised from repetition of the Sandertop Formation with the core formed by the white quartzites of the Berzelius Bjerg Formation (Fig. 4), but shearing has destroyed all original sedimentary structures.

A well developed axial plane schistosity is developed around Troldedalen dipping WSW at angles between $18^{\circ}$ and $38^{\circ}$, approximately parallel to the dip of the shear zone at the margin of the EGB outcrop.

A change in the trend of the north-east marginal shear zone from NNW-SSE to N-S is mirrored by the trace of the Troldedalen anticline (Fig. 2), suggesting that the
Fig. 4. Troldedalen fold pair at the north-east margin of the EBG tract. View to north-northwest, see right side of crosssection 4, Figure 9. K: Kempe Fjord Formation; S: Sandertop Formation; B: Berzelius Bjerg Formation: $\mathrm{SZ}$ : shear zone.

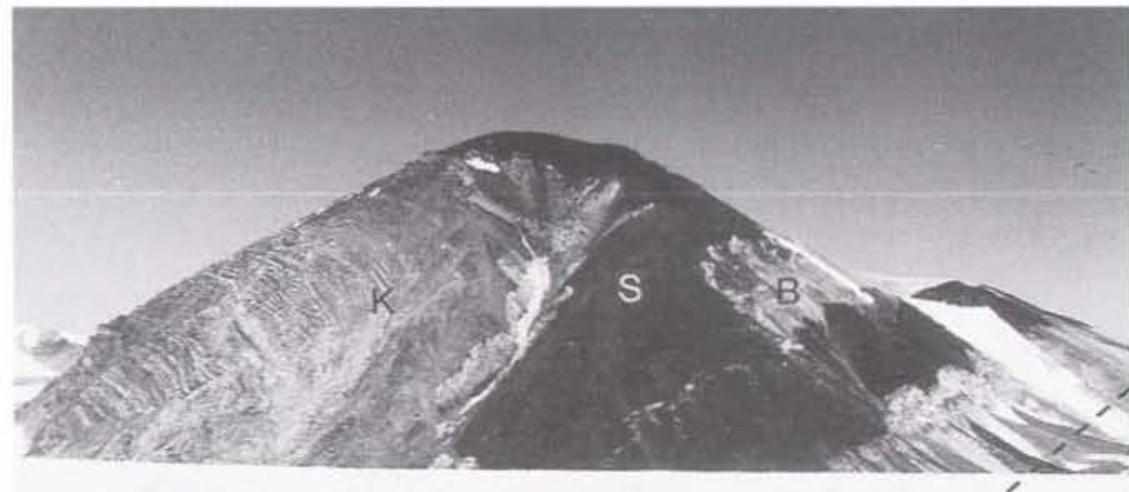

sz 


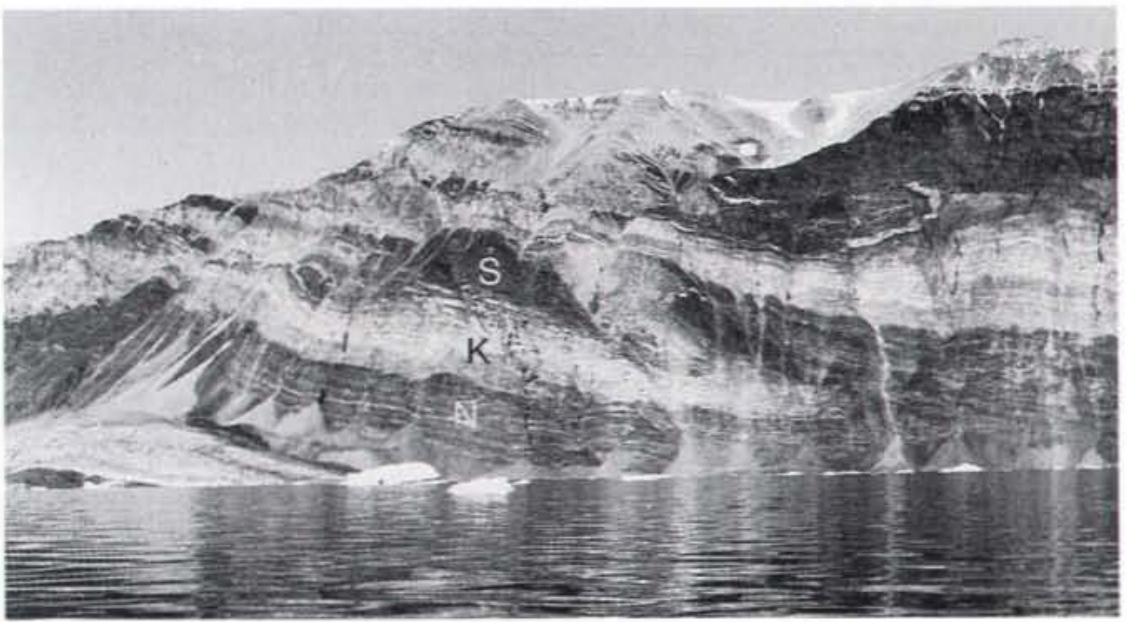

Fig. 5. North side of Ardencaple Fjord. Folds associated with Bradal fold pair disrupted by late faults. N: Nathorst Land Group: K: Kempe Fjord Formation: S: Sandertop Formation.

development of the fold is somehow controlled by the position and shape of the EBG-basement contact.

\section{Bradal fold pair and Smallefjord anticline}

The Brædal anticline and syncline can be traced along the north-east coast of Ardencaple Fjord and Bredefjord, the steep common limb forming the spectacular fjord walls between Kap Klinkerfues and Brædal (Figs. 5, 6).

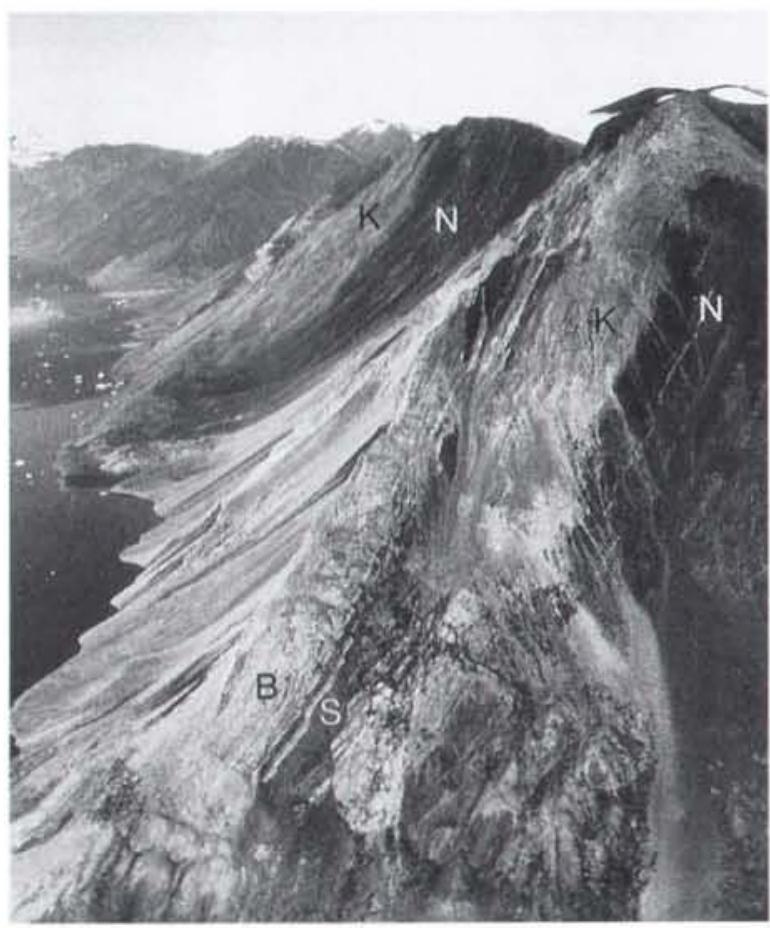

Fig. 6. Looking north-west along the north side of Bredefjord, dominated by the steeply inclined limb of the Bredal fold pair. N: Nathorst Land Group; K: Kempe Fjord Formation; S: Sandertop Formation: B: Berzelius Bjerg Formation.
In Bradal the steep limb is inverted, forming a panel of moderately inclined strata which Sommer (1957) was unable to correlate with the normal EBG succession. The same steep limb is also inverted at Kap Klinkerfues, where it is cut by the Kap Klinkerfues granite. Field and photogrammetric measurements show that the common steep limb has been thinned by up to $50 \%$, as illustrated in the cross-sections (Fig, 9).

The axial traces of this fold pair are in part hidden by Ardencaple Fjord and Bredefjord, but reconstruction of their positions shows a pronounced change in trend from NNW-SSE to WNW-ESE (Fig. 2) which appears to reflect a comparable change in trend of the EBG contact to the north-east. Reconstruction of the shape of the fold profile in a series of cross-sections (Fig. 9) shows that the folds are tightest near Kap Klinkerfues, and become gradually less pronounced to the north-west. Although the common limb is overturned near the mouth of Bradal, both folds are broad structures with interlimb angles of about $70^{\circ}$; north-west of Bradal the fold pair dies out rapidly.

An axial plane schistosity is well developed in rocks forming the steep fold limb along the north-east coast of Ardencaple Fjord and Bredefjord; it dips eastwards at angles of $60-80^{\circ}$.

The Smallefjord anticline (Fig. 7) is a broad, open N-S trending anticline crossing the mouth of Smallefjord, which is complementary to the Bradal fold pair. The trace of this anticline is approximately parallel to the present south-west boundary of the EBG tract, but the latter boundary in this area is a late fault.

\section{Knakso syncline, and associated folds}

The western margin of the EBG tract is marked by a syncline along Ejnar Mikkelsen Gletscher and Knæksø. 
Fig. 7. Smallefjord anticline, looking south across Ardencaple Fjord to the mouth of Smallefjord. S: Sandertop Formation; B: Berzelius Bjerg Formation: A: Kap Alfred Formation.

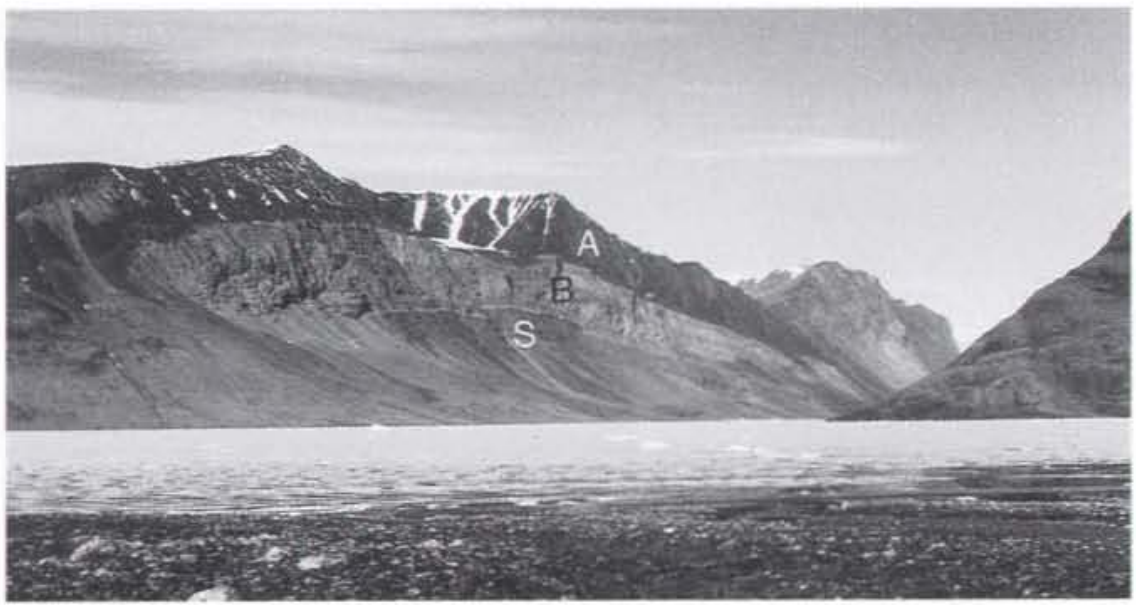

along which the strata turn up sharply towards the contact, providing another example of the apparent control of Caledonian fold geometry by the EBG-basement contact. Measured axial plane schistosities are generally steep. dipping ESE at angles between $50^{\circ}$ and $80^{\circ}$. As the EBG contact is approached, shearing increases in intensity and way up sedimentary indicators are lost. The actual contact zone is exposed infrequently, due to heavy moraine cover.

The Knaksø syncline has an approximately NNESSW trend. Complementary folds with parallel trends include a pronounced anticline which crosses the head of Bredefjord, where it is cut by the Bredefjord granite (Fig. 8 ) and less pronounced folds which traverse the high terrain north of Bredefjord (Fig. 2).

The NNE-SSW trends of the Knaksø syncline and related folds diverge markedly from the general NNWSSE trends of the Troldedalen and Bradal fold pairs and
Smallefjord anticline, and led Haller (1971) to postulate two distinct Caledonian fold phases.

\section{Metamorphism, granites and isotopic dating}

The distribution of metamorphic index minerals in the Ardencaple Fjord EBG is depicted in the inset to Figure 2. Metamorphic grade is essentially depth-related. The highest grades are encountered at sea level along the inner part of Bredefjord in the Nathorst Land Group where porphyroblastic garnet and staurolite coexist in completely recrystallised two mica-epidote schists. Commonly the porphyroblasts are seen to statically overgrow bedding with delicate sedimentary structures preserved, but elsewhere they are deformed in association with the development of new planar fabrics.

Garnet is also present in schistose Nathorst Land Group near the western border of the EBG tract beside
Fig. 8. Caledonian granite at the head of Bredefjord, cutting the NNE-SSW trending Bredefjord anticline formed in banded units of the Nathorst Land Group (lower EBG).

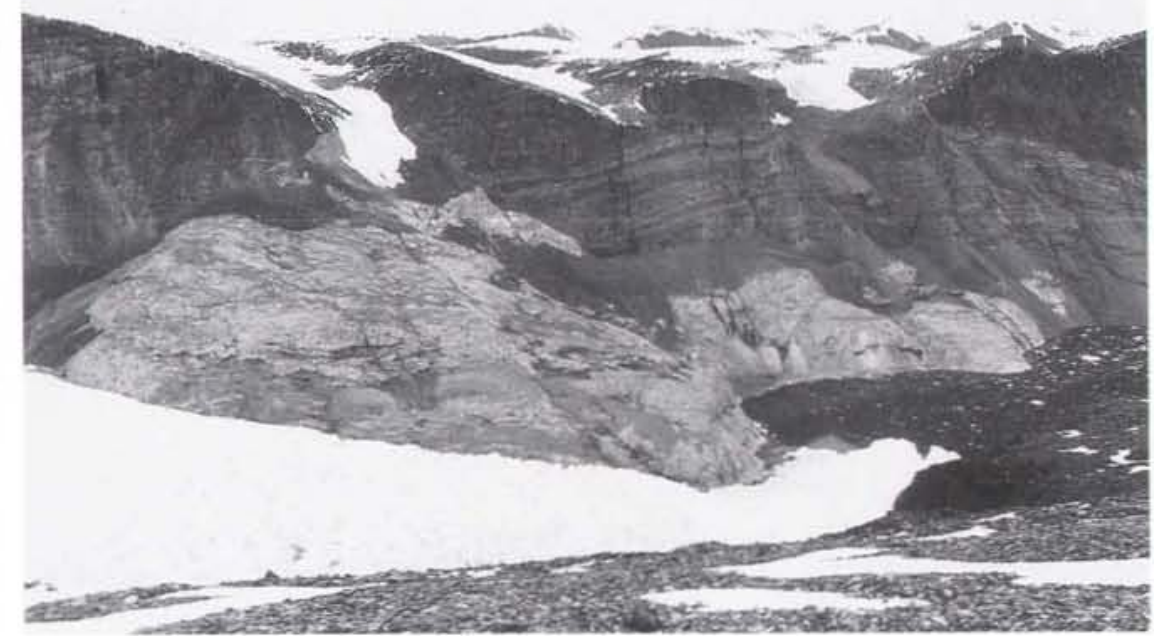



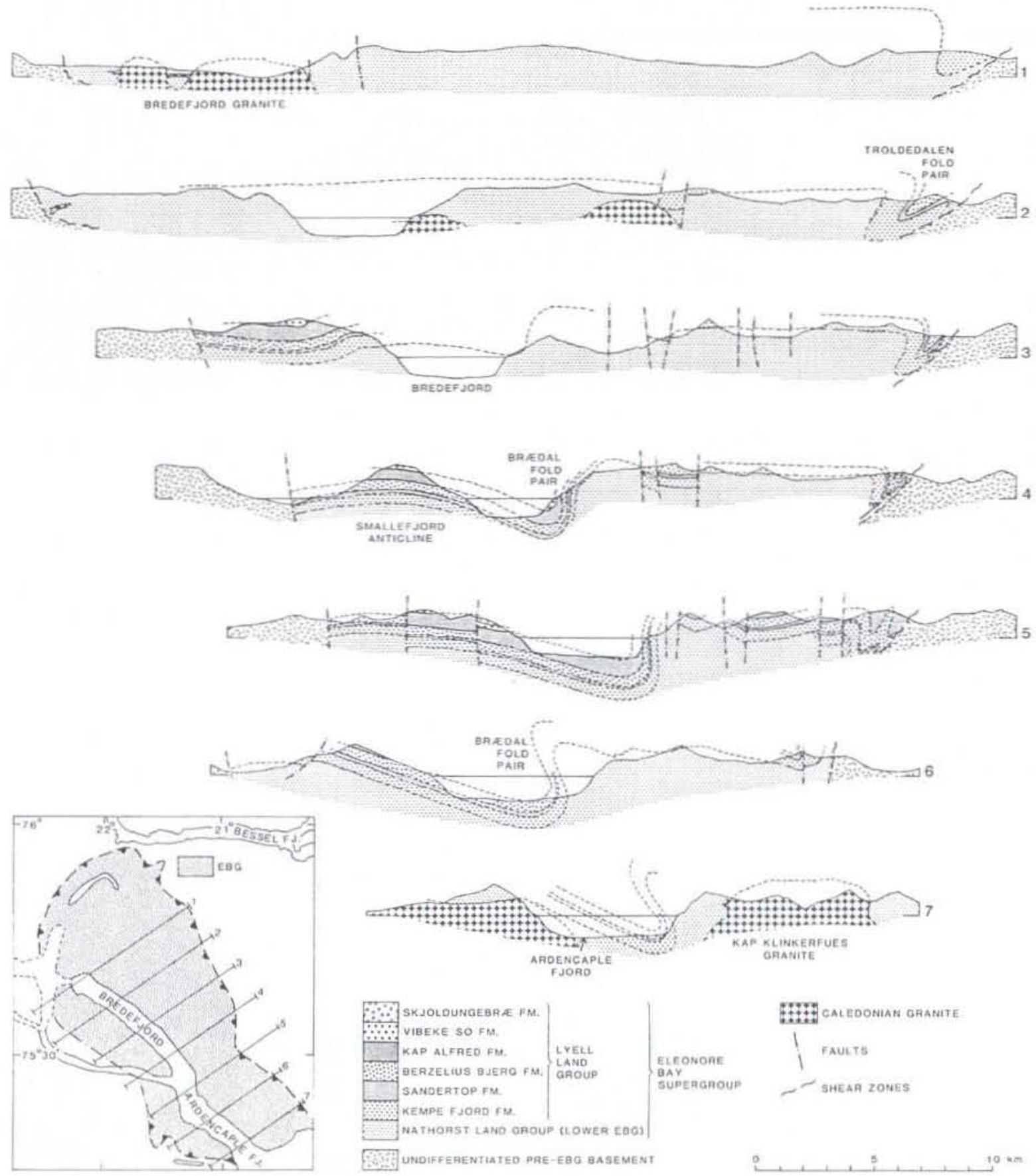

Fig. 9. Series of NE-SW cross-sections illustrating changes in fold profiles along strike. The line of section 4 is also plotted on the geological map of Figure 2.

Ejnar Mikkelsen Gletscher, and both garnet and staurolite near the northern border, where the porphyroblasts are strongly deformed and the micaceous matrix completely transposed into an intense planar fabric.

At higher stratigraphic levels, garnet and locally stau- rolite are present along the north-east margin of the EBG tract in the Kempe Fjord, Sandertop and Berzelius Bjerg Formations. In the core of the Brredal syncline, at sea level, garnet and andalusite are locally present in the Vibeke Sø Formation. 
The lowest metamorphic grades are found in flat-lying EBG strata near some of the highest summits at $1500 \mathrm{~m}$ altitude. Samples from the Kempe Fjord Formation east of Brædal and the Vibeke S $\emptyset$ Formation west of Kap Daly show almost unstrained and weakly recrystallised detrital textures with the limited development of new sericite.

${ }^{40} \mathrm{Ar}-{ }^{39} \mathrm{Ar}$ muscovite plateau ages of 415 and $400 \mathrm{Ma}$ have been obtained from two samples of garnet bearing schist collected from respectively the head of Bredefjord and the north-east marginal zone south of Bessel, Fjord (Dallmeyer et al., 1994; Dallmeyer \& Strachan, 1994). These are slightly older than ${ }^{40} \mathrm{Ar}-{ }^{39} \mathrm{Ar}$ muscovite ages obtained from crystalline rocks in nearby regions, and Dallmeyer $\mathrm{et} \mathrm{al}$. suggest the EBG tract may have formed part of a structurally high segment of the orogen which cooled through muscovite blocking temperatures ( $c$. $400^{\circ} \mathrm{C}$ ) earlier than surrounding basement gneisses. The ${ }^{40} \mathrm{Ar}-{ }^{39} \mathrm{Ar}$ ages establish a late Caledonian age for the metamorphism. It appears to have been an essentially depth-related thermal event, regardless of stratigraphic level, but with higher grades also spatially associated with the marginal shear zones, where deformation and fabric development outlasted the thermal peak.

Several intrusions of leucocratic two-mica granite are present in the Ardencaple Fjord EBG tract (Fig. 2). The well exposed granite at Kap Klinkerfues, which has given a U-Pb zircon age of $405 \pm 2 \mathrm{Ma}$ (Hansen et al., 1994) cuts across the Brrdal fold pair, while that on the opposite side of Ardencaple Fjord cuts across the EBG-basement contact in Kildedalen. Hansen et al. also record a $\mathrm{U}-\mathrm{Pb}$ zircon age of c. $382 \mathrm{Ma}$ for the granite at the east end of Knæksø; however, this discordant granite body has yielded a significantly older ${ }^{40} \mathrm{Ar}-{ }^{39} \mathrm{Ar}$ muscovite plateau age of $423 \mathrm{Ma}$, while the Bredefjord granite (Fig. 8) has given an ${ }^{40} \mathrm{Ar}-{ }^{39} \mathrm{Ar}$ muscovite plateau age of 411 Ma (Dallmeyer \& Strachan, 1994). These granites are interpreted as late Caledonian (early Devonian) intrusions which immediately post-date the main (probably late Silurian) deformation of the EBG.

\section{Basement-cover relationships}

The contact of the EBG against the surrounding metamorphic rocks in the Ardencaple Fjord area presents the same problems of interpretation as seen elsewhere in East Greenland: there is an apparent transition in metamorphic grade between the EBG and the underlying metamorphic complex, and the lowest recognisable EBG rocks belong to different stratigraphical levels from place to place. As the metamorphic complex includes Grenville and early Proterozoic elements, a sub-EBG unconformity must once have existed, but has been transposed by shear zones such that different stratigraphic levels of the EBG now abut against basement.

A particularly instructive section across the western contact occurs on the east side of Ejnar Mikkelsen Gletscher, a few kilometres north of the head of Smallefjord (west end of section 1, Fig. 9). A sharp contact can be identified between dark weathering psammites and biotite schists of the Nathorst Land Group and lighter coloured paragneisses. While the gneisses share a common fabric with the EBG schists, they undoubtedly possess an earlier gneissose texture. Two types of granitepegmatite sheets of presumed Caledonian age are present in both rock groups: small sub-concordant sheets foliated parallel to the common fabric, and larger weakly foliated and unfoliated sheets which are markedly cross-cutting. Both types are deformed by medium scale presumed Caledonian folds. These medium scale folds are superimposed upon minor folds which deform compositional banding in both groups and have downward-vergent geometry consistent with down-dip extension (Fig. 5 in Soper \& Higgins, 1993). Soper \& Higgins conclude that the EBG-basement contact at this location is essentially a pre-Caledonian extensional shear zone, subsequently intruded by granite sheets and folded during the Caledonian orogeny.

The Ardencaple Fjord area provides supplementary evidence for a pre-Caledonian age of the extensional phase. It is unlikely to have been associated with the period of subsidence which accompanied deposition of the EBG, as no facies changes are observed in the upper part of the succession as present boundaries are approached. As described above, the Caledonian folds follow the curvature of the eastern margin of the EBG tract, suggesting they were controlled by it. They verge up, outwards from the EBG, in the hangingwall of the marginal shear zone which apparently has the same sense of displacement, yet the hangingwall rocks are EBG cover while the footwall is composed of metamorphic basement. Soper \& Higgins argue that the boundaries of the present EBG tract must originally have been pre-Caledonian extensional structures (either faults or ductile shear zones depending on crustal level), and that Caledonian inversion has been insufficient to eliminate the 'younger on older' extensional relationship. Figure 10 gives a section across the EBG rocks of the Ardencaple Fjord area, together with a cartoon pre-Caledonian restoration showing potential positions of the extensional faults.

Soper \& Higgins (1993) extended this model to the other EBG tracts in East Greenland, and show that it can explain the preservation of the extensive remnants of the Late Proterozoic EBG as enclaves within the older metamorphic basement after Caledonian deformation and uplift. It is envisaged that deposition of the EBG on a vast, 


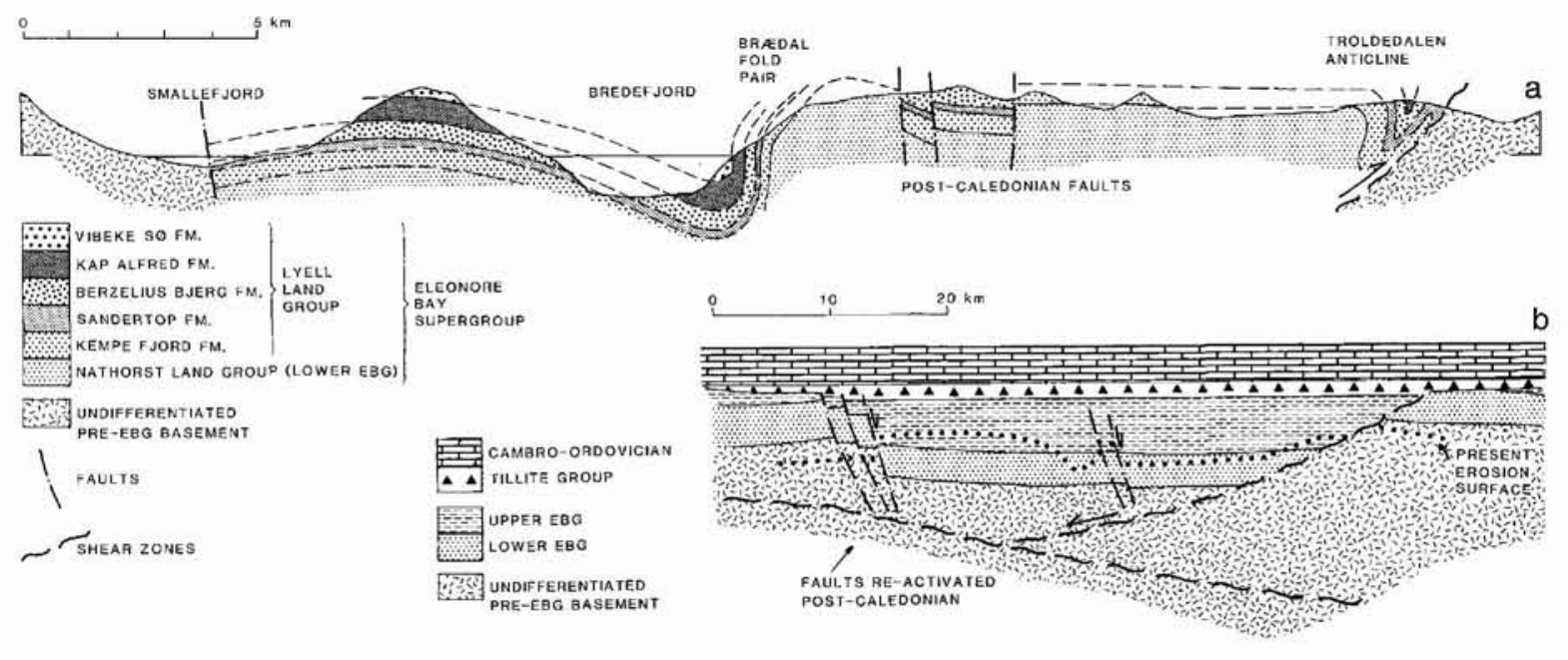

Fig. 10.(a) Section across the EBG rocks of the Ardencaple fjord area; section line shown on Fig. 2. (b) Cartoon pre-Caledonian restoration of section to show Vendian extensional faulting. The presumed presence of the Tillite Group and Cambro-Ordovician is speculative. After Soper \& Higgins (1993).

continuously subsiding intracontinental sag basin was brought to an end by major extensional faulting of Vendian age, which produced vertical displacements on faults and shear zones in excess of $10 \mathrm{~km}$. The Vendian age of this extensional episode is inferred from the manner in which the Tillite Group oversteps the EBG in the central fjord zone (Moncrieff, 1989). The positions of the Vendian extensional fault zones are shown in Figure 1. The presence of clasts of EBG lithologies and basement crystalline rocks in the two glacigenic formations of the Tillite Group suggests erosion of rift shoulders, while the lithofacies of the Tillite Group and its rapid thickness and facies changes identify it as a syn-rift sequence.

Vendian rifting and rift-related magmatism is widely recognised in more southerly parts of the Laurentian margin. In Scotland, eruption of the Tayvallich volcanics, dated at about $595 \mathrm{Ma}$ (Halliday et al., 1989), is thought to be related to the opening of Iapetus (e.g. Anderton, 1982). On the Appalachian margin, the age of rifting has been estimated from dates in the range 550-615 Ma from basic dykes in south-east Labrador (Kamo et al., 1989) and the Adirondack Mountains (Coish \& Sinton, 1992), and metafelsites in the St. Lawrence rift system (Kumarapeli et al., 1989). Bond et al. (1984) derived an age of 600 $\pm 25 \mathrm{Ma}$ for continental break-up by extrapolating thermal subsidence curves for the Cambro-Ordovician miogeoclinal sequence back to zero depth.

We would thus see the Vendian rift episode in East Greenland as part of a regionally important event, associated with continental break-up. It was predated by a long period of extensional subsidence during EBG deposition, and followed by Iapetus passive margin sedimentation that in the central fjord zone is represented by some $3 \mathrm{~km}$ of Lower Palaeozoic carbonates.

Caledonian deformation in East Greenland, arising from collision with Baltica as Iapetus closed, is represented in the EBG by limited flexural folding at high levels, but more pervasive strain at depth with fabric and metamorphic convergence across the earlier rift margin shear zones. Contractional displacements on the latter were less than the earlier extension, and this incomplete inversion of the Vendian rifts, coupled with post-Caledonian, pre-Atlantic extensional faulting, are the reasons why the extensive but isolated tracts of EBG cover rocks are now preserved within the basement complexes of the East Greenland Caledonides.

\section{References}

Anderton, R. 1982: Dalradian deposition and the late Precambrian-Cambrian history of the $\mathrm{N}$. Atlantic region: a review of the early evolution of the Iapetus Ocean. J. geol. Soc. Lond. 139, $421-431$.

Bond, G. C., Nickeson, P. A. \& Kominz, M. A. 1984: Breakup of a supercontinent between $625 \mathrm{Ma}$ and $555 \mathrm{Ma}$ : new evidence and implications for continental histories. Earth planet. Sci. Lett. 70, 325-345.

Coish, R. A. \& Sinton, C. W. 1992: Geochemistry of mafic dikes in the Adirondack Mountains: implications for late Proterozoic continental rifting. Contrib. Miner. Petrol. 110, 500514.

Dallmeyer, R. D. \& Strachan R. A. 1994: ${ }^{40} \mathrm{Ar} /{ }^{39} \mathrm{Ar}$ mineral constraints on the timing of deformation and metamorphism, North-East Greenland Caledonides. Rapp. Gronlands geol. Unders. 162 (this volume). 
Dallmeyer, R. D., Strachan R. A. \& Henriksen, N. 1994: ${ }^{40} \mathrm{Ar}{ }^{39} \mathrm{Ar}$ mineral age record in NE Greenland - implications for the tectonic evolution of the North Atlantic Caledonides. J. geol. Soc. Lond.

Friderichsen, J. D., Strachan, R. A. \& Henriksen, N. 1994: Basement-cover relationships and regional structure in the Grandjean Fjord - Bessel Fjord region $75^{\circ}-76^{\circ} \mathrm{N}$, North-East Greenland. Rapp. Gronlands geol. Unders. 162 (this volume).

Haller, J. 1970: Tectonic map of East Greenland (1:500,000). An account of tectonism, plutonism, and volcanism in East Greenland. Meddr Gronland 171(5), 286 pp.

Haller, J. 1971: Geology of the East Greenland Caledonides, 415 pp. London, New York, Sydney \& Toronto: Interscience Publishers.

Halliday, A. N., Graham, C. M., Aftalion, M. \& Dymoke, P. 1989: The depositional age of the Dalradian Supergroup: $\mathrm{U}-\mathrm{Pb}$ and $\mathrm{Sm}-\mathrm{Nd}$ isotopic studies of the Tayvallich volcanics, Scotland. J. geol. Soc. Lond. 146, 3-6.

Hambrey, M. J. \& Spencer, A. M. 1987: Late Precambrian glaciation of central East Greenland. Meddr Gronland Geosci. 19, $50 \mathrm{pp}$.

Hansen, B. T., Henriksen, N. \& Kalsbeek, F. 1994: Age and origin of Caledonian granites in the Grandjean Fjord - Bessel Fjord region $\left(75^{\circ}-76^{\circ} \mathrm{N}\right)$, North-East Greenland. Rapp. Gronlands geol. Unders. 162 (this volume).

Kalsbeek, F., Nutman, A. P. \& Taylor, P. N. 1993: Palaeoproterozoic basement province in the Caledonian fold belt of North-East Greenland. Precambrian Res. 63, 163-178.

Kamo, S. L., Gower, C. F. \& Krogh, T. E. 1989: Birthdate of the Iapetus Ocean? A precise $\mathrm{U}-\mathrm{Pb}$ zircon and baddleyite age from the Long Range dikes, southeast Labrador. Geology 17, 602-605.

Kumarapeli, P. S., Dunning, G. R., Pintson, H. \& Shaver, J. 1989: Geochemistry and U-Pb age of comenditic metafelsite of the Tibbit Hill Formation, Quebec Appalachians. Can. J. Earth Sci. 26, 1374-1383.
Moncrieff, A. C. M. 1989: The Tillite Group and related rocks of East Greenland: implications for Late Proterozoic palaeogeography. In Gayer, R.A. (ed.) The Caledonide geology of Scandinavia, 285-297. London: Graham \& Trotman.

Rex, D. C. \& Gledhill, A. R. 1981: Isotopic studies in the East Greenland Caledonides $\left(72^{\circ}-74^{\circ} \mathrm{N}\right)$ - Precambrian and Caledonian ages. Rapp. Gronlands geol. Unders. 104, 47-72.

Sommer, M. 1957: Geologische Untersuchungen in den praekambrischen Sedimenten zwischen Grandjeans Fjord und Bessels Fjord $\left(75^{\circ}-76^{\circ} \mathrm{N}\right.$. Br.) in NE-Grönland. Meddr Gronland $160(2), 56 \mathrm{pp}$.

Sønderholm, M. \& Tirsgaard, H. 1993: Lithostratigraphic framework of the Upper Proterozoic Eleonore Bay Supergroup of East and North-East Greenland. Bull. Gronlands geol. Unders. 167, $38 \mathrm{pp}$.

Sønderholm, M., Collinson, J. D. \& Tirsgaard, H. 1989: Stratigraphic and sedimentological studies of the Eleonore Bay Group (Precambrian) between $73^{\circ} 30^{\circ}$ and $76^{\circ} \mathrm{N}$ in East Greenland. Rapp. Gronlands geol. Unders. 145, 97-102.

Soper, N. J. \& Higgins, A. K. 1993: Basement-cover relationships in the East Greenland Caledonides: evidence from the Eleonore Bay Supergroup at Ardencaple Fjord. Trans. Roy. Soc. Edinb.: Earth Sci. 84, 103-115.

Steiger, R. H., Hansen, B. T., Schuler, C. H., Bär, M. T. \& Henriksen, N. 1979: Polyorogenic nature of the southern Caledonian fold belt in East Greenland: an isotopic age study. J. Geol. 87, 475-495.

Vidal, G. 1976: Late Precambrian acritarchs from the Eleonore Bay Group and Tillite Group in East Greenland. Rapp. Gronlands geol. Unders. 78, 19 pp.

Vidal, G. 1979: Acritarchs from the Upper Proterozoic and Lower Cambrian of East Greenland. Bull. Gronlands geol. Unders. 134, 40 pp.

Wegmann, C. E. 1935: Preliminary report on the Caledonian orogeny in Christian X's Land (north-east Greenland). Meddr Gronland 103(3), 59 pp. 